\title{
READING THE BIBLE IN AFRICA: ACCOUNTING FOR SOME TRENDS Further prolegomena for a discussion
}

\author{
Jeremy Punt \\ University of Fort Hare
}

\begin{abstract}
In an initial discussion on the interpretation of the Bible within and with specific attention to the African context, an attempt was made to get closer to a 'clarification' of important elements of 'African culture'. For many decades various interests rode roughshod over African culture, but lately there is concern to get closer to African cultural matters. In the process of denigrating African culture, the Bible has not only been part and parcel of the abuse but also suffered abuse by being kept from being read 'with African eyes'. However, African culture is not at all as monolithic as this expression intimate culture in Africa indeed differs, sometimes significantly, between groups and localities. Yet, all cultures could be said to have a dual nature and thus always seem to be dynamic and accommodating, liberating and oppressing, socialising and alienating, useful and irrelevant. This contribution aims to further the discussion and debate on the role of biblical studies in Africa by mapping out a few more contours of the Bible's appropriation in Africa as well as some general perceptions within the debate, all of which takes place within the context of African culture. Especially two issues will be taken under consideration, the first of which is as much characterised by confusion as the second is by disinformation: the debate on Afrocentrism as opposed to Eurocentrism, and the appropriation of the Bible in the African Independent Churches.
\end{abstract}

\section{Afrocentrism vs Eurocentrism}

The Eurocentric approach to theological hermeneutics has been dominant in Western cultures since the Enlightenment.' (Myers 1991:45)

Confusing the issues?

The abuse of the Bible in African context is often seen to reside in the imperialist Anglo-European approaches to biblical interpretation found even within Africa, and as done by and for Africans. It has become customary in African scholarship to react against Eurocentric presuppositions, values, and practices overpowering and guiding the study of the Bible and rightly so. In this context one finds the terms Eurocentric and Afrocentric which are not so much employed as particular hermeneutical-exegetical strategies in biblical interpretation, but rather with reference to the setting of the perimeters of biblical interpretation. Frequently, however, little or no discussion is provided on, either what the problem(s) seems to be with Eurocentrism or how Eurocentric readings of the Bible differ from Afrocentric readings.' It is the important starting point to oppose an Afrocentric

1. The often referred to example is that of Itumeleng Mosala (1989), who vehemently critiques African scholars (particularly Boesak and Tutu) for their use of Eurocentric ways of interpreting Scripture or at least tacitly accepting Eurocentred presuppositions and assumptions inherent to certain methodologies. However, Mosala avails himself of Materialist exegesis with its operating system build on Marxist class analysis. Cf. Domeris (1991:78); Martey (1993:136-137) who argues that Mosala's approach illustrates the inadequacy of 'orthodox Marxist analysis' which allows for the analyzing of class only, and effectively sidelines issues of race 
reading to a Eurocentric one while referring to the latter's undeniable legacy of justifying various kinds of oppression ${ }^{2}$ but eventually this approach seems insufficient on its own.

From a methodological perspective Myers (1991:46) lists a number of problems experienced with Eurocentric hermeneutics: it is too exclusive; assumes only one meaning in texts; views the text as merely a product of history; virtually excludes text-reception; is not narrative-conscious enough; passifies the reader; and, have the interests of a literate bourgeois class in mind. However, many of these 'problems' are in all fairness not restricted to interpretive practices which could be called Eurocentric, and indeed, have been identified and are addressed by 'Eurocentric' hermeneuts.

It seems as if more problems are created than solved with employing Eurocentric as a label to describe interpretive practice. Certainly some African scholars who debunk the generalised notion of 'African' as umbrella term quickly and effectively, are disproportionately slow in recognising the difficulty of generalising 'European' into a few rather vague suggestions like 'objectivism', 'individualism', and so on, all of which are represented as though neatly compacted in a monolithic and self-contained unit, ${ }^{3}$ and which are then employed as criticism of Eurocentricity. On a different but related level, one scholar (Myers 1991:44-50) goes so far as to virtually equate an Eurocentric reading of the Bible with the historical-critical method. The identification of the two is both unjustified towards some uses and users of the historical-critical method ${ }^{4}$ and does not seem to reckon with the fact that Eurocentric notions are not restricted to one particular hermeneutical method.

Moreover, although the ideological and power aspects wielded implicitly in Eurocentric readings of texts are eagerly pointed out, similar implications deriving from the use of Afrocentric readings of the Bible are either disregarded or even discarded. ${ }^{5}$ Yorke $(1995: 151)$ for example describes the Western or European ethos as 'racist and pathological' the perception if not verification of which is probably justified. However,

especially, as well as culture and gender; Mazrui (1980:62) who thinks that: 'For the time being it is a sociolinguistic impossibility for an African to be a sophisticated Marxist without at the same time being a 'substantially westernized' African.' Shutte (1988:7) questions the perceived parallels between the African conception of 'inter-dependence' which is 'personalist through and through', and 'European collectivism' where the individual is regarded functionally. Recently De Villiers (1993:17, n26) has questioned the ability of dialectical materialism, with its roots in the 19th century, pre-industrial Western European setting, to address the complex modern world.

An interesting aspect in the whole debate concerns the perceived materialist emphasis of African society, which is questioned by someone like Arowele (1990:431-432) who contends that in the traditional African view the material world, earth is not seen as 'home', but as 'market' (or 'field'); heaven is home, because heaven is the location of the seat of God and the community of ancestors.

In related way, in the North American situation the 'first wave of black theology was quickly criticized by many blacks for relying on standard academic insights and perspectives.' (Cormie 1991:176) For dissatisfaction with the 'European' emphasis as contrasted with an 'American' approach in biblical (Pauline) scholarship from a North American perspective, cf. Jewett (1994).

2. And other varieties of cultural imperialism and (attempted) cultural oppression, cf. Du Toit (1991:espec. 29$30)$.

3. One African scholar that does articulate this danger in generalising 'Western' is Maluleke (1995:20) who refers to the 'dubious construct' of 'Western culture'.

4. In the same edited work, many other contributions both affirm and illustrate the need for historical-critical study of the Bible. (Felder 1991) From an African American perspective, cf. also Wimbush's work referred to below.

5. Wimbush (1991:85) is willing to admit that African Americans did not take long 'to associate the Book of 'Book Religion' with power.' Cf. Bauckham (1989:18). 
apart from admitting to the "perspectival'" nature of all biblical interpretation (1995:148,153), Yorke fails to account for the ideological implications of his own reading. Furthermore, although I do not believe Yorke implies an 'anything-goes' approach with insistence on the guiding force of perspective, he fails to provide or apply any perimeters within which readings could responsibly and ethically operate.

The use of Afrocentric as description for an alternative to Eurocentric way of reading the Bible can truly and ultimately become useful if it is not defined and used exclusively in a critical or negative way, that is, with the only aim being to challenge Eurocentric readings. ${ }^{7}$ The constructive use of Afrocentric as a characterisation of a particular reading practice entails more than setting itself in opposition to Eurocentric readings, the latter which is in any case in need of articulation. The usage of an Afrocentric hermeneutic will also have to be subjected to the same 'hermeneutic of suspicion' or 'ideology criticism', and cannot naively be accepted as 'authentic' to Africa, and therefore universal and neutral or objective. As much as 'borrowed theological concepts and tools such as Western Philosophy' can and does distort the efforts of African theologians, so the 'traditional theological thought forms' of the 'African worldview' (Muzorewa 1990:169,173) have to be scrutinised for its accompanying baggage, ${ }^{8}$ including the presuppositions and assumptions that are carried within these thought forms, and the African worldview's 'ideological' strictures.'

Although aware of the high level of generalisation inherent to it, Maluleke (1995:20-23) uses the twin terms, 'African culture' and 'Western culture', deliberately and with the intention to stimulate dialogue and debate on the generalisations as such and on what Maluleke perceives to be the reasons for the, as he calls it, 'two lumps theory'. However, it soon becomes clear that Maluleke's purpose perhaps veers more closely to that of creating a straw-puppet with only one intent, namely to shoot it down. The frightening aspect is, that Maluleke seems not to notice how his own straw-puppet keeps shooting back and eventually hits him in the foot and thereby effectively halts any advances he so eagerly longs for. ${ }^{10}$

\section{Attempts at definitions}

In Felder's contribution it becomes clear just how helpful the attempt is to analyse and

6. The importance of perspective in reading is stressed by Yorke; cf. also Onwu (1984/5:43) on the 'early Christian missionaries' perceiving 'Christianity through their cultural lens'; Tienou $(1983: 89-91,100)$ on the influence of one's 'presuppositions' and the possibility of curtailing an all-determining 'hermeneutical key'; Ukpong (1995:5) on the various factors constituting the interpreter's 'conditionedness'. Martey (1993:56$57,106)$ argues that in African theology liberationists employs a hermeneutics of suspicion to account for the 'ideological interests and commitment of interpreters' whereas inculturationists stress only the importance of interpreting the Bible 'against the background of traditional African life and thought'.

7. Cf. similiar warnings by Sawyerr (1987:24), explaining the need to move from (through) the critical to the constructive. The warning of Rosemary Radford Ruether is appropriate, viz. that "black theologians constantly walk a 'razor's edge between a racist message and a message that is validly prophetic". (Quoted by Thistlethwaite 1995:268 who further points out that ' $(t)$ he racially explicit language of Black African Nationalism has also been explicitly anti-Semitic.') Conversely, cf. Maluleke (1995:20-21), who warns also that 'Eurocentric' is often employed only as a foil to 'African culture' in order to 'denigrate' the latter.

8. Cf. Combrink (1996b:289-290): ' $\ldots$ the Christian faith brings judgement on all cultural conditions.'

9. Ideology in the (Mannheim) sense of one's particular perception of and alignment in life, and to life itself. Cf. also Kawale (1995:24) who claims that the Bible has been used to 'legitimise' both Western and African cultures. Cf. Bauckham (1989:18).

10. Maluleke opposes multiculturalism because it 'precludes ... intercultural exploitation, discreditation and destabilisation' (1995:22); and, he is so locked in battle with Sono's challenge to black scholars in SA that it petrifies his arguments. (1995:20,23ff) 
to distinguish the two 'centric' concerns, even if such definitions doe not find general acceptance. Felder defines Eurocentrism in the biblical interpretive context as:

- the recasting of the entire biblical tradition into an ancient religious drama of Eurasian Hebrews who once sojourned in Egypt, which somehow was removed from black Africa, then evolved in an ancient Canaan that had little or no relation to Africa, and eventually gave rise to the birth of a European Jesus and Christianity as a 'Hellenistic' religion of the Greco-Roman world.' (Felder 1993/4:46)

On the other hand, Afrocentrism according to Felder (1993/4:47) means:

reestablishing Africa and its descendants as centers of value, without in any way demeaning other people and their historic contributions to world religion.

Similiarly, Afrocentricity:

is the idea that Africa and persons of African descent must be seen as proactive subjects within history, rather than as passive objects of Western history. ${ }^{11}$

The inherent dangers of Eurocentrism is located in its hierarchical and exclusivist designs according to Felder (1993/4:51), but these perils likewise lurks in a ill-designed Afrocentrism and multiculturalism to which Felder is all but oblivious. Felder analyses three strains ('types') in Afrocentrism: one which stresses corrective historiography, a second which argues for certain common cultural and other elements by which all black Africans are defined; and a third which Felder calls 'black nationalist'. In reaching for his goal of forging 'a new sense of common Christian identity or even shared citizenship, irrespective of race, gender, or class' (51).

Felder is 'skeptical' about the second type and 'reject(s) outright' the third. ${ }^{12}$

For Sanders (1993/4:11) there exists a threefold goal inherent to Afrocentricity, viz. the celebration of African achievements, critical analysis of the 'Eurocentric world view', and the construction of an 'alternative framework for understanding and evaluating human experience'. Especially in terms of the third aspect named by Sanders, the positing of an alternative approach to that of Eurocentric and I would like to include, narrow Afrocentric approaches to the Bible and its interpretation, is to a large extent lacking in Africa. In Southern Africa and the rest of the continent, it is becoming increasingly important to jettison our parochial notions of what constitutes a 'better' reading of the Bible, ${ }^{13}$ implying

11. These definitions are also subscribed to by Yorke. (1995:148-150) However, whether an Afrocentric reading of the New Testament primarily boils down to finding a 'pervasive presence of Africans' therein (153) and identifying the skin-colour of Jesus Christ as 'South African coloured' (152) is doubtful. Cf. Onwu's for whom the 'colour of Jesus' is irrelevant confrontation between the biblical Christ and the African worldview will contribute towards successful indigenisation. (1985:152; 1986:126)

The ambiguous treatment of the 'black presence' in the Bible cannot be dealt with here: the very basis of the argument for establishing the 'black presence' in the Bible, viz. the affirmation of the 'unity' of Africa (e.g. Felder 1993/4:53; Copher and other contributors to Felder 1991), is virtually denied by Martey (1993:4) with his distinction between 'Black' Africa and Northern Africa; the latter severing also church fathers like Cyprian, Tertullian and Augustine from 'Africa proper', contra Ben-Jochannan (1991:78-137).

The ambiguous nature of the Africa characterisations found in the Bible can also not be considered here, cf. Turkson (1994:80; also 80, n5) on Egypt as 'haven of slavery' and 'sanctuary and place of relief'.

12. Wambudta (1980:32) identifies 'nationalism in the garb of humanism' as 'a cryptic inhibiting force' in and wants it exposed as a threat for progress made towards a 'biblically based African Christian theology'.

13. This might also be part of the tendency referred to by Barr (1990:146-147) who argues that many readers have 'in the back of their minds' the idea that there is an 'orthodoxy' and that it is exactly what the Bible expresses. This 'mental attitude' is not only anachronistic given the pluralist nature of the Bible and its 
an absolute choice between an Afrocentric or Eurocentric perspective. Only by realising the many levels of reciprocal influencing contained in these expressions and the need to harness them together for all of our benefit, will we be able to make any kind of significant advances in the reading of the Bible.

It is simply impossible to use Afrocentric as though to the exclusion of 'Eurocentric' values, when the latter has influenced ${ }^{14}$ African experience and values through centuries of imperialistic designs on different levels of society: political, economical, cultural and certainly religiously. But then again 'Eurocentric' is not a sui generis, a purely European crafted 'entity': the values and perspectives of European people are not monolithic, and have developed and are still in a process of development as indeed is the case with all of human life and attributes in interaction with many 'cultures' over an extensive period of time. Perhaps the search for the origin and justification of specific 'centered'-approaches to the Bible should occupy a reemphasized place in our reading of Scripture, in favour of rather utilising the best on offer of African as well as European readings, and adding American, Asian and many other perspectives, so that the reading of Scripture from a multifaceted perspective or at least with an awareness of different perspectives and interests can take place, and precedence.

\section{Multiculturalism: a solution?}

From a North-American context Felder (1993/4:28-44) argues cogently for a multicultural approach to the reading of the Bible, which is his response to both a narrow Eurocentric and equally confined Afrocentric hermeneutic.

- 'Multiculturalism means above all that people who belong to different cultural traditions live together, indeed have to live together, in one and the same society.' (Collet 1994:26)

- Multiculturalism does not (necessarily) obviate the recognition of people in their cultural contexts, which is important, because as Root (1985:32) argues

- '(r)ecognizing a person's particular culture is to affirm their dignity and humanity.'

However, recognition of a person's culture should not exclusively focus on the differences but also on the 'common humanity' of people, in order to avoid 'artificiality, awkwardness and self-consciousness.'

A multiculturalism of integrity can take its cue from the New Testament writings, as Collet argues from Gal 3:16, wherein others are respected in their otherness while simultaneously being granted 'the right to a home'.

'This practice includes the rejection both of a ghetto-like self-assertion and of a strategic

context(s) but readers indeed interact as much with what they support in the Bible as with that which they react against.

14. Both negatively perhaps predominantly so! and positively. For example, amidst the ever-present realisation of the damage wreaked by European colonizers and missionaries in the life of African people (Maimela 1991:4) and their implicit and explicit participation of the systematic oppression of Africans, recently there is also a renewed, a 'post-naive' appropriation of the accomplishments of (non-African) missionaries in Africa. (e.g. Sanneh, quoted in Hiebert 1996:73; Waruta 1994:83). Cf. Maluleke (1995:20) who stresses the 'sometimes embarrassing as well as painful interdependence' between African and Western cultures; and, Wambudta (1980:33) who argues for a 'more balanced' approach, which acknowledge that the 'white' contribution to Africa had some benefits for Africa. The often used concept 'traditional', becomes problematical when it seems to imply a pure 'tradition out there', uninfluenced by other (Western, or modern) traditions and technology. 
take-over.' (Collet 1994:28)

In Collet's view, multiculturalism entails the adherence to both an 'unconditional reciprocal recognition' and a 'distinctive identity'. Collet maintains that the 'programmatic concept' according to which multicultural Christianity ceases to be mere description of a social situation but becomes normative for that reality is 'inculturation'.

Inculturation is understood as the church's concern to introduce the gospel into a particular social and cultural context in such a way that people can believe in their own values in this sphere, in so far as they are compatible with the gospel. (Collet 1994:29)

The importance of such a multicultural approach, based on inculturation, for African Christianity is not only essential but is a continuing serious and urgent matter for African theologians. Unfortunately interpretive practice regarding, and appropriation of the Bible within, a programme of multicultural inculturation often seems to be neglected.

An important criticism of multiculturalism ${ }^{15}$ derives from Baum whose argument (1994:104-106) is that it 'disguises rather than reveals the social reality of modern society'. Baum argues that the secondary culture is powerful and pervasive especially in the power of assimilation it exerts and that this is concealed by 'the multicultural discourse'. Although secondary culture has potential beneficial aspects like positive democratic notions and values when disguised by multicultural discourse, it leads to the destruction of primary cultures. Baum's point is that multiculturalism can come to exist only by virtue of people of various primary cultures subscribing to the secondary culture, which simultaneously supercedes and suppresses the primary cultures. Baum prefers the policy of 'convergence' which is advocated by the Quebec-government in Canada, opposing notions of integration and assimilation. The danger of multiculturalism becoming a mere imperialist ploy in the sense of a secondary culture based upon market forces, consumption mentality and 'integration effects' of democratic practices have to be reckoned with whether multiculturalism cannot overcome this hazard of an all-consuming secondary culture is another question. However, the possible ethnocentric and intolerant notions inherent in a 'policy of convergence' are equally grave perils.

\section{Conclusion}

Finally, one has to remember and take it seriously as Pobee (1992a:19-20) reminds us that:

(e)very contextual theology is partial truth and never the whole truth.

The realisation that the acceptance or validifying of contextuality implies the relativity

15. This term has been abused in many contexts in order to maintain the status quo in SA the Apartheid-regime even coined the slogan 'separate but equal', and the joke that some were just more equal than others turned sick and pathological. Felder realises the danger in promoting multiculturalism. (1993/4:46; so also Ackermann 1994:218; Sanders 1993/4:23) However, multiculturalism in the true, mutually reciprocal, and harmonious sense of the term is again advocated in SA, of which Archbishop Tutu's book on the South Africans as a rainbow nation is a prominent example. This metaphor has even gripped pop-musicians Chris de Burgh and Sting who has written songs on the same theme: the rainbow-people of SA! Naturally there are opponents to the reimaging of multiculturalism as a nation-building exercise in SA, cf. Maluleke (1996:22). However, Felder (1993/4:46) wants to employ multiculturalism in a constructive sense 'to transcend the politics of difference and thereby create a wholesome new spirit of joy in a life of Christian service to others'. Asante (quoted in Sanders 1993/4:16) has the same goal with his 'ecumenical' Afrocentricity: 'to transform human reality by ushering in a human openness to cultural pluralism which cannot exist without the unlocking of the minds of acceptance of an expansion of consciousness'. This stands in stark contrast to benJochannan's (quoted in Sanders 1993/4:16-20) 'exclusive Afrocentricity'. 
or partiality of one's own position, and in addition, requires when one strives towards accountability and responsibility in one's own theological endeavours that serious dialogue is encouraged and entered into with other theologies and theological approaches. ${ }^{16}$

Dyrness (1990:66) argues in my view correctly for a scriptural antecedent of multiculturalism in that as Paul denied Judaism as 'normative framework' for the appropriation and understanding of the Gospel during the first century, so today one should be equally careful of affirming by necessity an established framework, such as is found in 'European Christianity'.

The universal character of the Gospel lies in the fact that it tests all cultures, but also that it allows every people to make their contribution to the Kingdom of God. Without merely exchanging one extreme for another, the affirmation of a legitimate African perspective on the Bible, could also assist in the reconciliation between different races in Southern Africa and elsewhere in the world. Indeed, as Bellis (1995:33, cf 31) argues:

... if Africans were highly regarded in biblical times that objective information should have a positive impact on racial attitudes in the modern world.

\section{African traditional religions and African independent churches}

\section{The Bible and similiarities}

In the context of the formation of African theology, and on the role of the Bible therein, African Traditional Religions ${ }^{17}$ (ATRs) and the Bible are sometimes mentioned in the same breath:

'(t)ogether with the Bible, African traditional religion (ATR) is considered a major source of African theology.' (Martey 1993:72) ${ }^{18}$

Attempts are often made to reconcile the worldview, norms and values and other themes found in the Bible with that of traditional African piety and values. To suggest that ATRs are homogeneous, is generally regarded as insufficient and unhelpful in discussions on this matter. ${ }^{19}$ Turner (1980:15) refers to these religions as 'indigenous or primal', but also as 'many-hued' in Southern Africa and the rest of the continent. This he ascribes to the

'... great movements and mixtures of populations with different cultures and world views'.

A good example of the impossibility of a generalised concept like 'African' can be the traditional practice in some African societies of 'ancestral worship'. Although this practice is not to be found in all African societies (Pobee 1992b:28,63), yet very often this ancestor

16. Virtually the same point is made by Combrink (1996b:299) and West (1993:136). Cf. Schssler Fiorenza (1986:378).

17. The concept of African Traditional Religions is employed as a functional term to depict religious traditions indigenous to Africa, and is often used in conjunction with the term: African Indigenous (Initiated) Churches (AICs). The latter, however, can be seen as the result of the interaction of elements derived from ATRs and Christianity. Moribe (1994:75) argues that the AICs should be seen as 'africanised Christianity', because AICs 'never allowed' African religion to be 'christianised'.

18. Also Fashol-Luke (1975:81-82); Muzorewa (1990:171-172); Ngumi (1996:26); and, Sawyerr (1987:21-26). Cf. Pauw (1995:16): AICs 'represent radical indigenisation and Africanisation of Christianity'; Waruta (1994:86), who mentions the AICs' 'creative blending' of 'elements of African culture and religious heritage with their understanding of the Bible. For the sake of fairness, however, one needs to note that all theologies have more than the Bible as sources. (Barr 1990:133)

19. Cf. Dickson (1972:155); however, Anderson (1992:284) argues for both similiarities and differences between these religions. Platvoet refers to African Traditional Religion as a 'hypothetical construction'. 
veneration is held up as the distinctive African religious-cultural practice. ${ }^{20}$

The comparison between the Bible and ATRs often leads to an extensive search for parallels between the biblical and the African worlds, 21 and is exemplified in the contextualising of the Christian gospel found in the African Independent (or, Initiated) Churches (AICs). ${ }^{22}$

'The African indigenous church movement is considered a source for the definition of African theology mainly because it draws most of its insights from the traditional religion and culture when it indigenizes the faith.' (Muzorewa 1990:171)

Traditional African religious beliefs and practices are incorporated in various ways and differing extent into the AICs, because these practices especially are perceived to meet real problems and provide relief from it. (Maimela 1991:8) ${ }^{23}$

\section{On hermeneutics}

Daneel (1987:250) argues that the place and role of the Bible in AICs 'is focal and is accepted as the final authority. ${ }^{, 24}$

Although Daneel did find one church among the Shona who substituted the Bible with their own 'canonical documents', in general such documents are subordinary to the Bible. (Daneel 1987:252) However, in addition to having the Bible as primary source for its 'faith, the AICs manage to incorporate many of the traditional African norms, values, and beliefs by 'stripping Christianity of its foreignness which has been a great handicap and have shown that Christianity can be expressed and meaningfully informed by the African religiocultural reality.' (Opoku, quoted in Martey 1993:76)

According to Bediako, Turner saw the African Independent Churches as confirmation that the Bible is a book for all cultures elements of life in these churches are perceived to have certain clear analogies or even similiarities with aspects contained in the biblical text.

'With regard to Biblical Studies, Turner pointed to the independent churches' ability to penetrate into and participate in the realities of the Biblical world in their modern

20. Cf. the editorial in the JThSA (32) of 1980: 'The veneration of ancestors is an essential part of black African culture'; Badenhorst (1992:5) calls 'belief in the ancestral spirits ... one of the most important aspects of African traditional belief'; Becken (1993:335, quoting Anderson) refers to 'ancestor veneration' as 'the central feature of African religion'; and, Thagale 1995:6): 'The removal of ancestors from the African belief system would be tantamount to the destruction of the African worldview.' Recently, Kitshoff (1996:23-36) has shown as evidenced in oral history that Shembe who is often held up as a proponent of ancestor veneration, did not share in the 'traditional grassroots veneration of ancestors'. Cf. the debate in Challenge (volumes 32 and 33, 1995) between Nrnberger and Tlhagale, on whether 'ancestors' have a legitimate role to play in African Christianity.

21. Cf. e.g. Kawale (1995:7-30), who also provides a brief survey of work intended to suggest comparisons between biblical and traditional African concepts of God; also Renju (1980:113-118).

22. On the difficulty regarding the terminology for these churches, cf. Anderson (1995:283-285); Daneel (1987:29-34); Ngumi (1996:26); especially Hayes (1992:139-146) who also accounts historically for the different terminology; Pauw (1995:5); and, Van Zyl (1994:360-362). Daneel's study is a comprehensive treatment of Shona Independent Churches in Zimbabwe.

23. Maimela (1991:9) argues that African Christians embrace both ATRs and Christianity, because the former procures deliverence from daily evil in the world whereas the latter 'provide salvation in the hereafter'. Anderson, however, argues that AIC-members believe 'these churches ... to provide biblical answers for 'this worldly' needs'. (1996:174). The AICs lack of or limited involvement in socio-political liberation is pointed out by Anderson (1996:182), and criticised severely by Waruta (1994:90) who concludes that many AICs in Kenya 'are of no consequence in national life'.

24. Anderson contradicts himself in claiming first that the scriptural interpretations of 'charismatic leaders' having the 'ultimate authority' (1996:177), while asserting later that 'the authority of the biblical text and its interpretation ... is literal and assumed'. (1996:184). 
circumstances, citing the experience of dreams 'as a means of revelation at many critical junctures and for many prominent figures' in Scriptures.' (Bediako 1995:253-254)

The Bible is read and interpreted within the AICs in a 'pre-critical way' making use 'primarily of the normal or customary understanding of the literal words' and church members are guided in this by their everyday life experiences as well as their traditional beliefs. (Anderson 1996:173,176, referring also to Mesters and West) Anderson emphasises the role perceived to be played by the Holy Spirit in 'Pentecostal-type AICs', which corresponds with the pre-critical notion of the immediacy of interpretation. ${ }^{25}$ The AICinterpretation takes its point of departure from the vernacular, which is probably more often heard than read, given the high rate of illiteracy among church members. The different ways in which the Bible is used within AICs are catalogued by Anderson (1996:175) as:

- 'a source book of supernatural answers to human need';

- 'a rationale for practices which would not be considered biblical by other African pentecostals'; and,

- 'an ethical rule book conceived in a kind of fundamentalist way'.

Daneel reasons that the biblical interpretation found in the AICs, although sometimes 'fragmentary' are never deliberate distortions of the gospel message, but well-intended attempts to account for the 'holistic' worldview found in Africa, and the Bible! This claim is supported by Van Zyl (1994:365-366) who refers to the deliberate disavowal of systematic theologising or even hermeneutical methods in AICs, in favour of a free and creative approach to Scripture with an appeal to inspiration by the Holy Spirit. Topical preaching, without any serious exegetical concern for the biblical texts, are common.

However, Van Zyl emphasises the role of communities' beliefs and traditions on the interpretation of Scripture. He therefore finds the contribution made by AICs to the interpretation of the Bible first and foremost in the great value they put on the interpreting community. He cautions against an idealised portrayal of the AICs' interpretation where it is assumed that (only) an 'authentic' African view guides this interpretation. ${ }^{26}$ Van Zyl explains this when he indicates three 'backgrounds' or settings against which the AICs' biblical interpretation should be understood: church and religious, socio-political, and AIC ministerial practice. Van Zyl apparently wants to emphasise that in the AICs' hermeneutical practice a guiding (interpretive) role is played by the community. ${ }^{27}$

In as far as the reception of the 'inscribed' text of the Bible and the oral setting of the

25. Contrary to Anderson's view that the emphasis on the perceived involvement of the Holy Spirit in interpretation corresponds or 'paraphrases' (inter alia) Croatto's emphasis on the role of 'preunderstanding' in interpretation. (Anderson 1996:174) Croatto stresses the reader's own contribution (within the context of the interpretive community) to the production of meaning of texts, whereas Anderson perceives the role of the Holy Spirit as an 'external' (to the interpreter!) guide which 'enables people to better understand the Bible'.

26. This idealist portrayal could be explained by 'over-identification' with the African values. This is an 'ethnic, nationalist and/or religious phenomenon' which takes place in 'culturally deprived or retarded communities. (Wilson 1991:201) Cf. Collet (1994) who argues that 'theological romanticism' readily replaces the ruins of 'theological vandalism'.

27. Van Zyl neglects, however, to explain how the AICs functions as 'interpretive communities', viz. how a community determine which text is read, how it is read and understood and appropriated, in fact, how the community discloses (or contribute to, if not create) the scriptural meaning. Bailey (1995a:4-11;1995b:365366) comes closer to accounting for the role of communities in 'producing meaning' when he refers almost anecdotally to the regulating function of the community in the oral communication of Middle Eastern communities where he conducted research; cf. Anderson (1996:173). Naude (1996:18-31) argues for the need of an 'Oral Theology' in South Africa which is built on Oral Theory and which takes the nature of orality as oral communication serious. 
AICs is concerned, Parratt warns against the imposition of a radical contrast between the Bible and traditional religions in Africa.

'The dichotomy between a written religious tradition (the Bible) and an oral one (African Religions) is not wholly valid. Both traditions share a similiar development from the oral to the written'. (Parratt 1983:90) ${ }^{28}$

Regarding the appropriation of the Bible within the AICs with the goal of 'Africanising' the texts or its interpretation, Chidester (1991:25) considers the position of the Bible in the AICs along ideological lines. Quoting Mzimba, Chidester contends that the AICs interpretation of the Bible wanted to establish 'African control' of the Bible in order to rescind the 'white man's' interpretation of it. The Bible now assumes a position beyond that of religious or sacred symbol only, and the ownership of the Bible becomes a crucial issue.

In his evaluation of the severely impoverished biblical hermeneutic found in Contextual Theologies, De Villiers (1993:21) argues that AICs, however, have succeeded not only in avoiding a reductionist approach to the Bible and so reflecting the dynamics of Scripture but also in empowering communities and in restoring human dignity. It should then be clear that in African Christian Theology ATRs and the Bible are within the African context seen as important sources of theological reflection. The attempts by the AICs to appropriate the Bible is a relevant way for the African context, is however still in need or more elucidation and should become an important avenue of research on biblical studies and hermeneutics in (South) Africa. ${ }^{29}$

\section{Conclusion}

In this contribution some further comments were made with the intention of identifying some more perimeters in the discussion on the use of the Bible in Africa. As has been argued earlier, there is an increasing need to concentrate on a particular African cultural group with its particular 'differences', rather than to revert to generalised conceptions of things 'African'. There is also a need to realise that especially in Africa the 'Eurocentric' Stoic values of aloofness and disinterestedness should be pushed aside:

'Many people will continue to want both to study the New Testament with integrity and to give allegiance to its central figure'. (Houlden 1989:408)

Similiarly, attempts to 'Africanise' the Bible might obscure and disempower the biblical message in stead of illuminating it, and may eventually fall prey to the same imperialism inherent in 'Eurocentric' readings.

Although the neglect or often unconcern with biblical studies in Africa can be ascribed to various factors, and the legacy of the abuse of the Bible in Africa will probably be with us for some time, the equally important aspect of the continuing reading and appropriation of the Bible in Africa as it is found in the AICs, cannot be ignored. African biblical studies clearly displays in what way cultural assumptions, beliefs and values play a role in African theology.

With the above comments in mind, let us not be in such a haste to 'prove' the Bible and its content to be subscribed to African culture(s) as if the Bible is the exclusive product of Africa. Let us similiarly 'defamiliarise' the Bible in terms of the now 'commonly accepted' 'Western-framework' in which it is often read. Let us accept that the Bible is an ancient,

28. Cf. the same caution against the postulation of such radical contrast (e.g. Walter Ong) advocated by Ruth Finegan. (Quoted in Naude 1996:20) Such a radical contrast s indeed proposed by Mazamisa (1995:1-26).

29. Cf. contributions by G West (1995a) and A Anderson (1996) in this regard. 
Middle-Eastern oriented set of documents espousing a great many and different views, in languages sometimes very difficult for us to fully comprehend. Let us also accept and rejoice that the Bible has been appropriated by African people, never to be relinquished again; the same Bible is not only read but used in the lives of people in Africa in many different ways. The twin dangers which we should avoid is the one of viewing the Bible as uninterpretable locked up in either in its 'own' past or the past of the 'history of its interpretation' and thus useless for Africa, and the other of assuming the aim of the Bible being to promulgate and promote Africanness, addressing us as an African document. 


\section{BIBLIOGRAPHY}

1980. Editorial. Journal of Theology For Southern Africa 32:2.

Ackermann, DM 1994. Women, religion and culture. A Feminist Perspective on 'Freedom of Religion'. Missionalia 22(2):212-226.

Aichele, G et al. 1995. The Postmodern Bible. The Bible and Culture Collective. New

Haven \& London: Yale University Press.

Anderson, A. 1995. Challenges and Prospects for Research into AICs in Southern Africa. Missionalia 23(3):283-294.

Arowele, PJ 1990. The Pilgrim People of God (An African's Reflections on the Motif of Sojourn in the Epistle to the Hebrews). Asian Journal of Theology 4(2):438-455.

Badenhorst, DC 1992. The Limitations and Possibilities of the South African Education System in the Inculcation of Values. Scriptura 41:1-12.

Bailey, KE 1995a. Informal Controlled Oral Tradition and the Synoptic Gospels. Themelios 20(2):4-11.

Bailey, KE 1995b. Middle Eastern Oral Tradition and the Synoptic Gospels. Expository Times 106(12):363-367.

Banana, CS 1993. The Case For a New Bible. In 'Rewriting' the Bible: The Real Issues. Perspectives from with Biblical and Religious Studies in Zimbabwe, eds. Mukonyora, I, JL Cox and FJ Verstraelen (co-ordinator), 17-32. Religious and Theological Series, vol. 1. Gweru: Mambo.

Barr, J 1980. The Bible as Political Document. Bulletin for John Rylands Library 62: 268-289.

Barr, J 1990. The Bible in the Modern World. (Reissued) London: SCM.

Bauckham, R 1989. The Bible in Politics. How to reas the Bible Politically. Third Way Books. London: SPCK.

Baum, G 1994. Two Question Marks: Inculturation and Multiculturalism. Concilium 2:101-106.

Becken, H-J 1993. Beware of the Ancestor Cult! A Challenge to Missiological Research in South Africa. Missionalia 21(3):333-339.

Bediako, K. 1995. Christianity in Africa. The Renewal of a Non-Christian Religion. Studies in World Christianity, vol. 1. Edinburgh: Edinburgh University Press.

Bediako, K 1996. Understanding African Theology in the 20th Century. Bulletin for Contextual Theology in Southern Africa \& Africa 3(2):1-11. (Previously published in Themelios 20(1):14-20)

Bellis, AO 1995. Objective Biblical Truth Versus the Value of Various Viewpoints: a False Dichotomy. Horizons in Biblical Theology 17(1):25-36.

Ben-Jochannan, YAA 1991. African Origins of the Major 'Western Religions'. Baltimore: Black Classic Press.

Bird, P 1994. Authority and Context in the Interpretation of Biblical Texts. Neotestamentica 28(2):323-337.

Brueggemann, W 1991. Interpretation and Obedience. From Faithful Reading to Faithful Living. Minneapolis: Fortress.

Byaruhanga-Akiiki, ABT 1993. Africa and Christianity: Domestication of Christian Values in the African Church. In Religious Plurality in Africa. Essays in honour of John S 
Mbiti, eds. Olupona, JK and SN Sulayman, 179-195. Religion and Society, vol. 32. Berlin/New York: Mouton de Gruyter.

Byaruhanga-Akiiki, ABT 1994. Culture as Source of Oppression of Women in Africa. In Maimela, S (ed), 32-47.

Carroll R, MD 1994. Context, Bible ans Ethics: a Latin American Perspective. Themelios 19(3):9-15.

Chidester, D 1991. Worldview Analysis of African Indigenous Churches. Journal for the Study of Religion 2:15-29.

Collet, G 1994. From Theological Vandalism to Theological Romanticism? Questions about a Multicultural Identity of Christianity. Concilium 2:25-37.

Combrink, HJB 1991. Die Bybel Lewe in Afrika. Acta Theologica (2):81-90.

Combrink, HJB 1996a. Translating or Transforming Receiving Matthew in Africa. Scriptura 58:273-284.

Combrink, HJB 1996b. The Reception of Matthew in Africa. Scriptura 58:285-303.

Copher, CB 1989. Three Thousand Years of Biblical Interpretation With Reference to Black Peoples. In African American Religious Studies. An Interdisciplinary Anthology, ed. Wilmore, G, 105-128. Durham and London: Duke University Press.

Cormie, L 1991. Revolutions in Reading the Bible. In Jobeling, D, PL Day \& GT Sheppard (eds), The Bible and the Politics of Exegesis, 173-193. Cleveland: Pilgrim.

Costa, RO 1988. One Faith, Many Cultures. Inculturation, Indigenization, and Contextualization. The Boston Theological Institute Annual Series, vol. 1. Maryknoll: Orbis.

Craffert, PF 1995. Is the emic-etic distinction a useful tool for cross-cultural interperetation of the New Testament? Religion \& Theology 2(1):14-37.

Daneel, ML 1987. Quest For Belonging. Introduction to a Study of African Independent Churches. Mambo Occasional Papers - Missio-Pastoral Series, vol. 17. Gweru: Mambo.

Davies, WD 1986. Reflections on Thirty Years of Biblical Studies. Scottish Journal of Theology 39:43-64.

De Villiers, PGR 1993. The Bible and the Struggle (for Power). Scriptura 45:1-28.

Dickson, KA 1972. African Traditional Religions and the Bible. In Mveng, E \& RJZ

Werblowsky (eds), The Jerusalem Congress on Black Africa and the Bible, April 24-30, 1972. Jerusalem: Israel Interfaith Committee.

Domeris, WR 1991. Reading the Bible Against the Grain. Scriptura 37:68-81.

Du Toit, CW 1991. Christianity against Cultural Domination and Cultural Plurality. Scriptura 38:27-38.

Dyrness, WA 1990. Learning About Theology From the Third World. Grand Rapids: Academie Books (Zondervan Publishers).

Fashol-Luke, EW 1975. The Quest for African Christian Theology. Journal of Religious Thought 32(2):69-89.

Felder, CH (ed). 1991. Stony the Road We Trod. African American Biblical Interpretation. Minneapolis: Fortress.

Felder, CH 1993/4. Afrocentrism, the Bible, and the Politics of Difference. Journal of Religious Thought 50(1-2):28-44.

Fiensy, D 1987. Using the Nuer Culture of Africa in Understanding the Old Testament: An Evaluation. Journal For the Study of the Old Testament (38):73-83. 
Fowl, SE 1995. The New Testament, Theology, and Ethics. In Hearing the New Testament. Strategies For Interpretation, ed. Green, JB, 394-410. Grand Rapids: Eerdmans.

Hammond-Tooke, WD 1974. World-view I: A System of Beliefs. In Hammond-Tooke, WD (ed), The Bantu-speaking Peoples of Southern Africa, 318-343. London and Boston. Routledge \& Kegan Paul.

Hargrave, S 1993. Culture, Abstraction, and Ethnocentrism. Missiology: An International Review 20(1):3-11.

Hayes, S 1992. The African Independent Churches: Judgement Through Terminology? Missionalia 20(2):139-146.

Hiebert, PG 1991. Critical issues in the Social Sciences and Their Implications for Mission Studies. Missiology 24(1):65-82.

Hinga, TM 1992. The Biblical Mandate for Social Transformation: a Feminist Perspective. In Mugambi, JNK \& A Nasimiyu-Wasike (eds), 37-47.

Houlden, JL 1989. Today and Tomorrow in Biblical Studies. III. A Future For New Testament Studies. Expository Times 100(11):405-408.

Jewett, R 1994. Paul: the Apostle to America. Cultural Trends and Pauline Scholarship. Louisville: Westminster/John Knox.

Kawale, WR 1995. Divergent Interpretations of the Relationship Between Some Concepts of God in the Old Testament and in African Traditional Religions a Theological Critique. Old Testament Essays 8:7-30.

Kealy, J 1976. The Irrelevance of the Bible. African Ecclesial Review 18(6):348-354.

Keith, GA 1995. Review of, Bediako, K 'Theology and Identity: the Impact of Culture upon Christian Thought in the Second Century and Modern Africa'. Themelios 20(3):32.

Kitshoff, MC 1996. Isaiah Shembe's Views on the Ancestors in Biblical Perspective. Journal of Theology for Southern Africa 95:23-36.

Knig, A 1981. Contextual Theology. Theologica Evangelica 14(3):37-43.

Knig, A 1994. Future Human Relationships in South Africa. In Mouton, JC \& BC Lategan, The Relevance of Theology for the 1990's, 303-313. Pretoria: HSRC.

Krüger, JS July 1993. Religion on the Canvas of Human Evolution. CSD/SWO Bulletin, 10, 13.

Lategan, BC 1993. Teaching Theology in the Context of the Humanities. Scriptura (S11):28-35.

LeMarquand, G 1995. A Bibliography of the Bible in Africa: A Preliminary Publication. Bulletin for Contextual Theology in Southern Africa \& Africa 2(2):6-40.

Maimela, SS Traditional African Anthropology and Christian Theology. Journal of Theology for Southern Africa 76:4-14.

Maimela, SS (ed). 1994. Culture, Religion and Liberation. Proceedings of the EATWOT Pan African Theological Conference, Harare, Zimbabwe, January 6-11, 1991. Pretoria: Penrose.

Maimela, SS 1994. Religion and Culture: Blessing or Curses? In Maimela, SS (ed), 1-17.

Malina, BJ 1991. Reading Theory Perspective: Reading Luke-Acts. In The Social World of Luke-Acts. Models for Interpretation, ed. Neyrey, J, 3-23. Peabody: Hendrickson.

Malina, BJ 1993. The New Testament World. Insights from Cultural Anthropology. Rev ed. Louisville: Westminster/John Knox Press. 
Maluleke, TS 1996. African Culture, African Intellectuals and the White Academy in South Africa - Some Implcations For Christian Theology in Africa. Religion and Theology 3(1):19-42.

Martey, E 1993. African Theology. Inculturation and Liberation. Maryknoll: Orbis.

Mazamisa, W 1995. Re-reading the Bible in the Black Church: Towards a Hermeneutic of Orality and Literacy. Journal of Black Theology 9(2):1-26.

Mazrui, AA 1980. The African Condition. A Political Diagnosis (The Reith Lectures). London: Heinemann.

Mbiti, JS 1978. The Biblical Basis in Present Trends of African Theology. Africa Theological Journal 7:72-85.

Mbiti, JS 1986. Bible and Theology in African Christianity. Nairobi: Oxford University Press.

Meeks, WA 1986. The Moral World of the First Christians. Library of Early Christianity, ed. Meeks, WA. Louisville: Westminster/John Knox Press.

Mofokeng, TA 1988. Black Christians, the Bible and Liberation. Journal of Black Theology in South Africa 2:34-42.

Moribe, S 1994. The Calling and Service of the African women in the African Independent/Indigenous Churches. Ned Geref Teologiese Tydskrif 35(1):68-76.

Mosala, IJ 1989. Biblical Hermeneutics and Black Theology in South Africa. Grand Rapids: Eerdmans.

Mothlabi, M 1986. The concept of morality in African tadition. In Tlhagale, B \& I Mosala (eds), 85-100.

Moulder, J 1992. Moral Education in a Multi-Cultural Environment Like South Africa's. Acta Academica 24(2):16-26.

Moyo, A 1992. Material Things in African Society: Implications for Christian Ethics. In Mugambi, JNK \& A Nasimiyu-Wasike (eds), 49-57.

Mugambi, JNK \& Nasimiyu-Wasike, A 1992. Moral and Ethical Issues in African Christianity. Exploratory Essays in Moral Theology. African Christianity Series, vol. 3. Nairobi: Initiatives.

Muzorewa, G 1990. A Definition of a Future African Theology. Africa Theological Journal 19(2):168-179.

Myers, WH 1991 The Hermeneutical Dilemma of the African American Biblical Student. In Felder, $\mathrm{CH}$ (ed), 40-56.

Naud, P 1996. Theology with a New Voice? The Case for an Oral Theology in the South African Context. Journal of Theology for Southern Africa 94:18-31.

Nengwekhulu, RH 1994. The Dialectical Relationship Between Culture and Religion in the Struggle For Resistance and Liberation. In Maimela, SS (ed), 18-31.

Ngumi, G 1996. The African Initiated Churches Affirming the Identity, Channeling the Power. Bulletin for Contextual Theology in Southern Africa \& Africa 3(2):26-28.

Nolan, A Oct/Nov 1995. Ubuntu. Challenge, 10.

Nolan, A June/July 1996. Are You a Racist too? Challenge, 10.

Nthamburi, Z 1992. Morality in Public Life. In Mugambi, JNK \& A Nasimiyu-Wasike (eds), 107-118.

Ntreh, BA 1990. Towards an African Biblical Hermeneutical (sc. Model). Africa Theological Journal 19(3):246-254. 
Nrnberger, K Oct/Nov 1995. Ancestors and Christ. The Power of the Dead Or the Risen Christ: Make Up Your Mind. Challenge, 4-5.

Oduyoye, MA 1995. Christianity and African Culture. International Review of Mission 86(332/3):77-90.

Onwu, N 1984/5. The Current State of Biblical Studies in Africa. Journal of Religious Thought 42(2):35-46.

Onwu, N 1985. The Hermeneutical Model: the Dilemma of the African Theologian. Africa Theological Journal 14(3):145-160.

Onwu, N 1986. A Hermeneutical Model for Africa. Theology Digest 34(2):123-126.

Parratt, J 1983. African Theology and Biblical Hermeneutics. Africa Theological Journal 12(2):88-94.

Pauw, CM 1995. African Independent Churches as a 'People's Response' to the Christian Message. Journal for the Study of Religion 8(1):3-25.

Pillay, G Theology in the 1990's: Towards a Reformulation of the Anthropological Question. In Mouton, J \& BC Lategan (eds), The Relevance of Theology for the 1990's, 315-327. Pretoria: HSRC.

Pobee, JS 1985. Teaching the New Testament in an African Context. Journal of Religious Thought 42(2):22-29.

Pobee, JS 1992a. In Search of Christology in Africa. In Exploring Afro-Christology, ed. Pobee, JS, 9-20. Studies in the Intercultural History of Christianity, vol. 79. Frankfurt am Main: Peter Lang.

Pobee, JS 1992b. Skenosis. Christian Faith in an African Context. Mambo Occasional Papers - Missio-Pastoral Series, vol. 23. Gweru (Zimbabwe): Mambo Press.

Pobee, JS 1993. Europe as a Locus Theologicus. Ecumenical Review 45(2):194-201.

Renju, PM 1980. African Traditional Religions \& Old Testament: Continuity or Discontinuity? In Angang, DAS et al (eds), Christianisme Et Identite Africaine, 113118. Kinshasa: Missionswissenschaftliches Institut Missio-Aachen.

Root, J 1985, Issues for the Church in a Multi-Racial Society. Themelios 10(2):30-36.

Sanders, C 1993/4. Afrocentricity and Theological Education. Journal of Religious Thought 50(1-2):11-27.

Sawyerr, H 1987. What is African Theology? In Parratt, J (ed), A Reader in African Christian Theology, 12-26. TEF Study Guide, vol. 3. London: SPCK.

Schssler, W 1995. Paul Tillich's Dynamic Concept of Faith. Theology Digest 42(3):247252.

Schssler Fiorenza, E 1986. Toward a Feminist Hermeneutics: Biblical Interpretation and Liberation Theology. In McKim, DK (ed), A Guide to Contemporary Hermeneutics. Major Trends in Biblical Interpretation, 358-381. Grand Rapids: Eerdmans.

Schtz, JH 1976. Ethos of Early Christianity. In Interpreter's Dictionary of the Bible, ed. Buttrick, G, 289-293.

Shutte, A 1988. Umuntu Ngumuntu Ngabantu: an African conception of humanity. Paper delivered at the Annual PSSA conference.

Thistlethwaite, SB 1995. Christology and Postmodernism. Interpretation 49(3):267-280.

Tienou, T 1983. Biblical Foundations: An African Study. Evangelical Review of Theology 7(1):89-101.

Tlhagale, B Oct/Nov 1995. Christianity and Tradition Compatible. Challenge, 5-6. 
Tlhagale, B \& IJ Mosala (eds). 1986. Hammering Swords Into Ploughshares. Essays in Honor of Mpilo Desmond Tutu. Grand Rapids / Trenton: Eerdmans / Africa World Press.

Turkson, PK 1994. De Taal van de Bijbel en Afrika. Wêreld en Zending 23(3):24-80.

Turner, HW 1980. Theological and Religious Studies in South Africa: Reflections of a Visitors. Journal of Theology for Southern Africa 30:3-18.

Ukpong, JS 1995. Rereading the Bible with African Eyes. Journal of Theology for Southern Africa 91:3-14.

Van Zyl, DC 1994. Die Bydrae van Afrika-Christene tot die Interpretasie van die Bybel die Interpreterende Gemeenskap. Nederduits Gereformeerde Teologiese Tydskrif 35(3):359-366.

Wambudta, DN 1980. Hermeneutics and the Search for Theologia Africana. Africa Theological Journal 9(2):29-39.

Waruta, D 1994. Religion as a Source of Oppression or Resistance: an Analysis of the Kenyan Situation. In Maimela, SS (ed), 77-96.

West, GO 1993. No Integrity Without Contextuality: the Presence of Particularity in Biblical Hermeneutics and Pedagogy. Scriptura S11:131-146.

West, GO 1995a. Biblical Hermeneutics of Liberation. Pietermaritzburg: Cluster.

West, GO 1995b. Reading the Bible in Africa: Constructing Our Own Discourse. Bulletin for Contextual Theology in Southern Africa and Africa 2(2):1-5.

Wilson, B 1991. 'Secularisation': Religion in the Modern World. In Clarke, P \& S Sutherland (eds), The Study of Religion, Traditional and New Religions, 195-208. The World's Religions, vol. 4. London: Routledge.

Wimbush, VL 1991. The Bible and African Americans: an Outline of an Interpretive History. In Felder, $\mathrm{CH}$ (ed), 81-97.

Witbooi, B 1987. Liminality, Christianity and the Khoikhoi Tribes. In Tlhagale, B \& IJ Mosala (eds), 101-110.

Yorke, GL 1995. Biblical Hermeneutics: an Afrocentric Perspective. Religion \& Theology 2(2):145-158. 